\title{
Emotional Experience and Microhistory
}

Emotional Experience and Microhistory explores the life and death of Magnús Hj. Magnússon through his diary, poetry and other writing, showing how best to use the methods of microhistory to address complicated historical situations.

The book deals with the many faces of microhistory and applies its methodology to the life of the Icelandic destitute pauper poet Magnús Hj. Magnússon (1873-1916). Having left his foster home at the age of 19 in 1892, he lived a peripatetic existence in an unstinting struggle with poor health, together with a ceaseless quest for a space to pursue writing and scholarship in accord with his dreams. He produced and accumulated a huge quantity of sources (autobiography, diary, poems, reflections) which are termed by the author as "egodocuments". The book demonstrates how these egodocuments can be applied systematically, revealing unexpected perspectives on his life and demonstrating how integration of diverse sources can open up new perspectives on complex and difficult subjects. In so doing, the author offers an understanding both of how Magnússon's story has been told, and how it can give insight into such matters as gender relations and sexual life, and the history of emotions.

Highlighting how the historiographical development of modern scholarship has shaped scholars' ideas about egodocuments and microhistory around the world, the book is of great use and interest to scholars of microhistory, social and cultural modern history, literary theory, anthropology and ethnology.

Sigurður Gylfi Magnússon is Professor of Cultural History and chair of the Department of History at the University of Iceland. He is also chair of the Center for Microhistorical Research. His latest books in English are What is Microhistory? Theory and Practice (2013) co-authored with István M. Szijártó, and Minor Knowledge and Microhistory (2017), co-authored with Davíð Ólafsson. He is the founder and an editor of the book series "The Anthology of Icelandic Popular Culture" (Sýnisbók íslenskrar alpýðumenningar) and also co-editor with István M. Szijártó of the series "Microhistories," published by Routledge. 


\section{Microhistories}

Series editors: Sigurður Gylfi Magnússon and István M. Szijártó

The Microhistories series is open to books employing different microhistorical approaches, including global microhistories aimed at grasping world-wide connections in local research, social history trying to find determining historical structures through a micro-analysis, and cultural history in the form of microhistories that relate directly to large or small scale historical contexts. They are interesting stories, that bring the everyday life and culture of common people of the past close to the readers, without the aspiration of finding answers to general "big questions" or relating them to the grand narratives of history. The series is open to publishing both theoretical and empirical works, but with a focus on empirical monographs which can communicate stories from the past and capture the imagination of our readers.

\section{Published}

The Revolt of Snowballs

Murano Confronts Venice, 1511

Claire Judde De Larivière

\section{A Tale of a Fool?}

A Microhistory of an 18th-Century Peasant Woman

Guðný Hallgrímsdóttir

\section{Roman Tales}

A Reader's Guide to the Art of Microhistory

Thomas V. Cohen

Puritan Family and Community in the English Atlantic World

"Much Afflicted with Conscience"

Margaret Manchester

Five Parishes in late Medieval and Tudor London

Communities and Reforms

Gary G. Gibbs 
The Great Nightmen Conspiracy

A Tale of the 18th Century's Dishonourable Underworld

Tyge Krogh

Production of Locality in the Early Modern and Modern Age

Places

Angelo Torre

Emotional Experience and Microhistory

A Life Story of a Destitute Pauper Poet in the 19th Century

Sigurður Gylfi Magnússon

Power in the Village

Social Networks, Honor and Justice among Immigrant Families from Italy to Brazil

Maira Ines Vendrame

For more information about this series, please visit: https://www.routledge. com/Microhistories/book-series/MICRO 
$\Longrightarrow$ Taylor \& Francis

Taylor \& Francis Group

http://taylorandfrancis.com 


\section{Emotional Experience and Microhistory}

A Life Story of a Destitute Pauper

Poet in the 19th Century

Sigurður Gylfi Magnússon

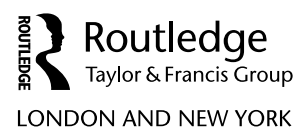


First published 2020

by Routledge

2 Park Square, Milton Park, Abingdon, Oxon OX14 4RN

and by Routledge

52 Vanderbilt Avenue, New York, NY 10017

Routledge is an imprint of the Taylor \& Francis Group, an informa business

\section{(C) 2020 Sigurður Gylfi Magnússon}

The right of Sigurður Gylfi Magnússon to be identified as author of this work has been asserted by them in accordance with sections 77 and 78 of the Copyright, Designs and Patents Act 1988.

All rights reserved. No part of this book may be reprinted or reproduced or utilised in any form or by any electronic, mechanical, or other means, now known or hereafter invented, including photocopying and recording, or in any information storage or retrieval system, without permission in writing from the publishers.

Trademark notice: Product or corporate names may be trademarks or registered trademarks, and are used only for identification and explanation without intent to infringe.

British Library Cataloguing-in-Publication Data

A catalogue record for this book is available from the British Library

Library of Congress Cataloging-in-Publication Data

A catalog record has been requested for this book

ISBN: 978-0-367-35996-6 (hbk)

ISBN: 978-0-429-34315-5 (ebk)

Typeset in Sabon

by Integra Software Services Pvt. Ltd. 


\section{Contents}

List of figures

Acknowledgments

\section{PART I}

The normal exception and stories from the people 1

1 Creating a story 3

2 Real people and fictional ones 14

3 The individual and microhistory 20

4 The normal exception 27

5 The book 30

\section{PART II}

Emotional communities in the life and death of Magnús Hj. Magnússon

1 In hostile waters 37

2 A harsh life on the farm of Hestur 40

3 Courtship 51

4 Matters of life and death 61

5 Matthildur's death and the poets 64

6 Saved by the Salvation Army? $\quad 70$

7 Rape: wrongful ruling? $\quad 80$

8 The High Court 92

9 Two contrasting arguments: new sources 96 
viii Contents

10 Days of hope and fear 103

11 Eternal life 111

\section{PART III}

$\begin{array}{ll}\text { In the company of few } & 115\end{array}$

1 A pointillist portrait of a person $\quad 117$

2 The conceptual framework of sex and sexuality 122

3 Microhistory, material culture and death 133

4 Fiction and microhistory 140

$\begin{array}{lr}\text { Bibliography } & 148\end{array}$

Index 159 


\section{Figures}

1 Map of the West Fjords (Iceland) 5

2 Cover of the book Ljós heimsins (in English World Light) by

3 A self-portrait of Magnús Hj. Magnússon 10

4 Manuscripts written by Magnús Hj. 12

5 The Day of the Diary - poster 16

6 The diary of Magnús Hj. Magnússon: a writing sample 31

7 The interior of the Icelandic turf houses 41

8 Cover of the memoirs of Kristín Dahlstedt 54

9 A page from the diary of Magnús $\mathrm{Hj}$. 56

10 Súgandafjörður around the turn of the 20th century 59

11 The town of Ísafjörður 62

12 The Salvation Army Hall in Ísafjörður, 1922

13 Guðrún and Skarphéðinn 73

14 The village of Bolungarvík - two photos 83

15 The Reykjavík jail around $1900 \quad 101$

16 Cleaning and drying fish 105

17 Housing in Iceland 120 


\section{Acknowledgments}

This book has been a long time in the making. I have been working with the ideas discussed here for more than a quarter of a century. Egodocuments have certainly informed my entire approach to history; I have made use of these documents in a range of studies of 18th-, 19th- and 20thcentury history. Hence parts of my arguments have been published in journal articles and books, as well as discussed in seminars, in many conferences across Europe and the United States and in private conversations with friends and colleagues. All this academic conversation has had a formative influence on my ideas and thinking. Some of the material which is discussed in my earlier books and articles has been reworked into this book. I am grateful to journals and publishing houses, both in Iceland and in Europe, for their permission to use some of the text in this book for arguing specific points. Special thanks to the University of Iceland Press, Routledge and Reaktion Books; passages which have previously been published are indicated in the book when used in any form or shape.

The extraordinary generosity of many colleagues around the world who have been in touch with me, first through the Reykjavík Academy and the Center for Microhistorical Research, and later the University of Iceland, has affected the development of my thinking a great deal. I would also like to express my gratitude to my specialist in the English language - Anna Yates - who helped with the text; editing parts of the book, reworking and translating some of the text. It has been extremely valuable for me to have access to her expertise, and have the opportunity for interaction with so patient a person as she - a specialist who has shown my work, in this book and others published in recent years, both interest and understanding. For any scholar, it is a great good fortune to have access to experts who are able to contribute to different projects, and Anna Yates is certainly in a class of her own in such work. I also wish to thank my friends and colleagues of many years' standing, Assistant professor Davíð Ólafsson and Professor Jón Karl Helgason at the Faculty of Icelandic and Comparative Cultural Studies, University of Iceland, and also my doctoral students, who have enriched the project in so many ways; Anna Heiða Baldursdóttir, Finnur Jónasson, and Sólveig Ólafsdóttir. I have been working on this 
project in recent years both as a professor of history at the Department of History, University of Iceland, and as a visiting scholar at the University of California, Santa Barbara, USA, 2016-17. I am grateful for all the support I have received from colleagues on both sides of the Atlantic in the development of this book.

I hereby acknowledge that the project was partly funded by the Icelandic Research Fund - IRF 184976-051 (in Icelandic: Rannsóknasjóður) - a Grant of Excellence for the project "My Favourite Things: Material Culture Archives, Cultural Heritage and Meaning," where I am the principal investigator (PI - see: http://hh.hi.is). I am grateful for the Fund's support for this threeyear project. It has been a stimulating and satisfying intellectual experience to work with this talented and diverse set of people mentioned above.

I dedicate this book to my parents, Magnús Helgason (1916-2000) and Katrín Sigurðardóttir (1921-), for all their love and support throughout the years. 
$\because$ Taylor \& Francis

Taylor \& Francis Group

http://taylorandfrancis.com 
Part I

The normal exception and stories from the people 
$\because$ Taylor \& Francis

Taylor \& Francis Group

http://taylorandfrancis.com 


\section{Creating a story}

To the farm of Fótur under the mountain Fótarfótur, in Heimsljós (World Light) by Nobel Prize-winning Icelandic novelist Halldór Kiljan Laxness, came a pauper named Jósep as a long-term resident. Before long he had bonded with the protagonist of the story, Ólafur Kárason Ljósvíkingur (i.e. from Ljósavík), who was a pauper too. Initially Jósep was skeptical; he had difficulty believing that anyone would "turn towards him in good faith", as it is put in the novel. But in due course Jósep shared his story:

Anyway, he had no regrets about having made the acquaintance of poets. Some men became rich and had fine progeny and retired with dignity in their old age - but they had never made the acquaintance of poets. What was their life worth?

"I have seen all my seven children die; the earth took some, the sea took the others; some were fully grown, some died in childhood. And I have lost their mother, and all my closest relatives, and I myself had to give up my farm and go on the parish after living in the same croft for forty years - but what does that matter? I had Guðmundur Grímsson of Grunnavík for a friend. At any time I was ready to lead my only cow out of the barn and take it to him if he needed it, even if it meant depriving my own children of their sustenance. If I had the chance of living my whole life over again and having all my seven children alive, but doing without the friendship of Guðmundur Grímsson of Grunnavík, I would not accept it. Guðmundur Grímsson of Grunnavík is a master and a sage. $\mathrm{He}$ is undoubtedly the greatest living master and sage in Scandinavia."1

This narrative is true. It did not happen in reality, but it is true in the sense that it is evocative of the mindset of people who grew up within the same peasant culture in which Laxness places his story. That is not to say that everyone thought as old Jósep did, or perceived reality in the same

1 Halldór Kiljan Laxness, World Light, trans. from the Icelandic by Magnús Magnússon (New York: Vintage International, 2002), pp. 45-46. 


\section{The normal exception}

way as he. The relationship with reality is primarily indirect, in this way: many people went through appalling mental torment at that time, when it was not unusual to see one's family, friends and relatives die in the prime of life. The narrative is set just after the middle of the 19th century, when infant mortality in Iceland was, for instance, around $35 \% .^{2}$

Narratives of such life experience abound in Icelandic egodocuments; and a surprising aspect is that at the same time the writers were keenly seeking out material to read and copy - on a larger scale than one might have expected in 19th-century conditions. ${ }^{3}$ The most unlikely people appear to have been willing to sacrifice almost anything in order to be able to nourish their minds on materials that lifted them above their day-to-day toil. ${ }^{4}$ Jósep is in effect an extreme example of the kind of people who have been the subjects of research in microhistory: a reflection of Ólafur Kárason Ljósvíkingur himself - the protagonist of Laxness' World Light - and hence also of the model for that character, peasant scholar Magnús Hj. Magnússon from the West Fjords, as manifested in his diaries. ${ }^{5}$ Magnús' diaries and his life will be one of the main focuses of this book. We shall explore the story of his life primarily in this book, which will address his tribulations specifically - and Magnús' life was both well-documented and dramatic.

"From when I was in my ninth year, and all the time until 1896, I felt that the countenance of God was open to me everywhere; it was as if I heard all of nature echo the sound of divine revelation, and I myself was part of that flood of voices, it seemed to me. Yet I felt that my part was so small in all that glory", ${ }^{6}$ writes Magnús $\mathrm{Hj}$. Magnússon in his unpublished autobiography, which he started to write on 12 January 1914. And many who are familiar with Laxness' writings will find those words reminiscent of a passage of World Light:

2 Ólöf Garðarsdóttir, Saving the Child: Regional, Cultural and Social Aspects of the Infant Mortality Decline in Iceland, 1770-1920 (Umeå: Umeå University Press, 2002), pp. 49-105.

3 Sigurður Gylfi Magnússon, "From Children's Point of View: Childhood in Nineteenth Century Iceland”, Journal of Social History 29 (Winter 1995), pp. 295-323; Sigurður Gylfi Magnússon, The Continuity of Everyday Life: Popular Culture in Iceland 1850-1940, Ph.D. dissertation, Carnegie Mellon University, USA, 1993; Sigurður Gylfi Magnússon, Menntun, ást og sorg: Einsögurannsókn á íslensku sveitasamfélagi 19. og 20. aldar [Education, Love and Grief: A Microhistorical Study of Rural Society in Iceland in the 19th and 20th Centuries], Sagnfræðirannsóknir 13 (Reykjavík: Sagnfræðistofnun Háskóla Íslands og Háskólaútgáfan, 1997).

4 Sigurður Gylfi Magnússon and Davíð Ólafsson, Minor Knowledge and Microhistory: Manuscript Culture in the Nineteenth Century (London: Routledge, 2017).

5 See my discussion of Magnús in: Sigurður Gylfi Magnússon, ed., Kraftbirtingarhljómur Guðdómsins: Dagbók, sjálfscevisaga, bréf og kvœði Magnúsar Hj. Magnússonar skáldsins á Pröm [The Sound of Divine Revelation], Sýnisbók íslenskrar albýðumenningar 2 (Reykjavík: Háskólaútgáfan, 1998).

6 Lbs 2238 4to - Æfisaga Magnúsar Hjaltasonar. Rituð af sjálfum honum. Byrjuð á Suðureyri í Súgandafirði, 12. janúar 1914. [The Autobiography of Magnús Hjaltason]. 


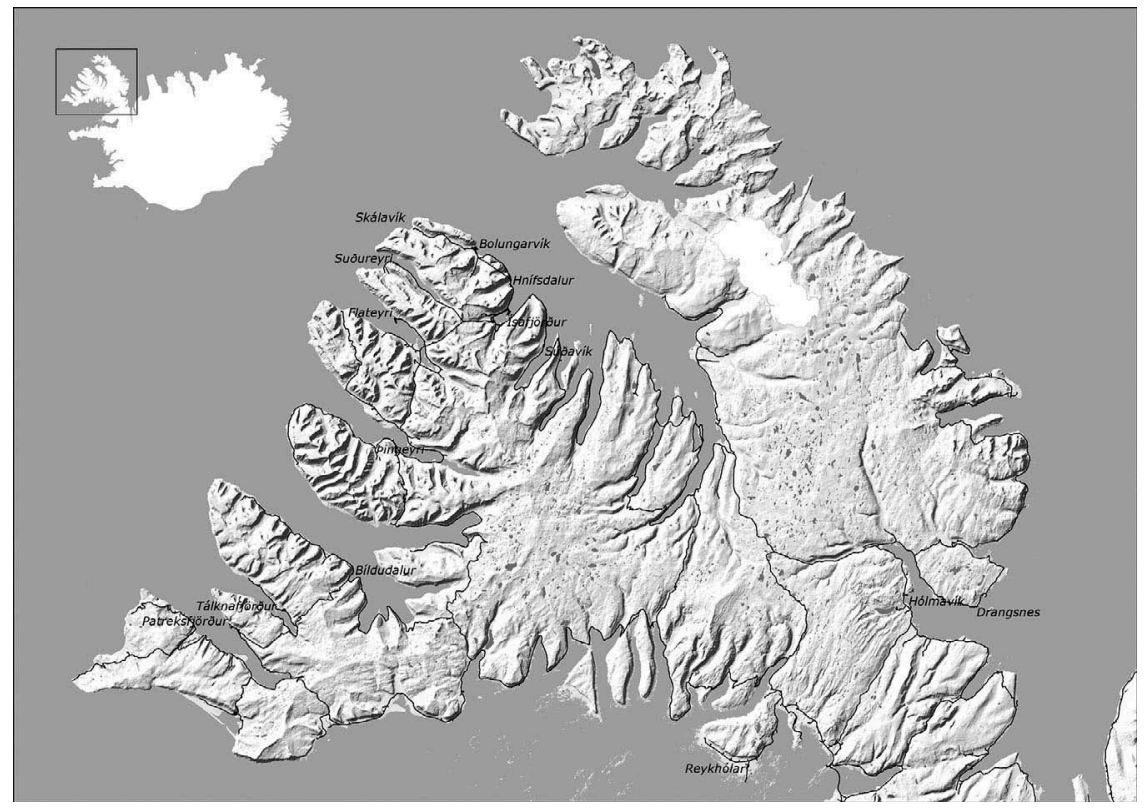

Figure 1 Map of the West Fjords (Iceland)

The story of Magnús Hj. Magnússon takes place in Iceland's West Fjords. This map shows the principal places in the region where Magnús and his family lived. The West Fjords was a hard place to make a living, as mountains reach down to the sea with minimal lowland, and hence there is limited potential for agriculture and animal husbandry. The fishing industry remained technologically primitive. The landscape of the region is rugged and mountainous; when people needed to travel from place to place, it was often necessary to traverse demanding highland routes which could be hazardous, especially in winter. In 1900 the population of the West Fjords was just over 12,000; people lived in small coastal villages and in widely dispersed inland communities in the many fjords. Magnús never had a horse to ride and made all his journeys on foot, often travelling with his wife and children. There was no transport network as such: no roads, only paths which had been trodden over the centuries. On occasion Magnús was lucky, and had use of a pack horse for his luggage, loaned by some fellow-traveller. But he was rarely so fortunate, and as a rule he had to carry his luggage on his back.

Landmælingar Íslands (National Land Survey of Iceland) 
He was not quite nine years old, in fact, when he first began to have spiritual experiences. He would be standing down by the bay, perhaps, in the early days of spring, or up on the headland to the west of the bay where there was a mound with a rich green tussock on top, or perhaps up on the hill above the homefield when the grass was high and ready for mowing. Then suddenly he felt he saw God's image open before him. He felt the deity reveal itself in Nature in an inexpressible music, the sonic revelation of the deity; and before he knew it he himself had become a trembling voice in a celestial chorus of glory. His soul seemed to be rising out of his body like frothing milk brimming over the edge of a basin; it was as if his soul were flowing into an unfathomable ocean of higher life, beyond words, beyond all perception, his body suffused by some surging light that was beyond all light. Sighing, he became aware of his own insignificance in the midst of this infinite chorus of glory and radiance; his whole consciousness dissolved into one sacred, tearful yearning to be allowed to be one with the Highest and be no longer any part of himself. ${ }^{7}$

Laxness indisputably makes good use of the material he has from Magnús, with masterful use of key words and concepts to intensify the effect of these thoughts, so that the reader senses the powerful impressions of both - Ólafur Kárason and Magnús Hj. Magnússon.

When comparing passages like these, it is necessary to bear in mind the circumstances and motivation that lie behind their creation. The Nobel Prize-winning novelist sits and works with his fabled diligence, writing one draft after another, constantly revising and polishing until the final proof is approved and the printing press takes over. The outcome is a text which is near-unparalleled for literary merit and imagination in the history of world literature in the 20th century.

Magnús kept a diary for 24 years, starting at the age of 19 in 1893 . For most of his life he was a destitute pauper, sometimes a lausamaður (a semiindependent worker, not bound to a single master) or a purrabúðarmaður (a cottar, or landless laborer), and occasionally a home school teacher. His life was harsh, from cradle to grave. While he was always a poor man, he enjoyed considerable freedom as a lausamaður, in comparison with many other people from the same social class. He also decided to write his autobiography, and in addition he collected various interesting information. There were not many drafts for his life story; life itself had absolute priority - and indeed life was often so precarious that the slightest setback could mean disaster and destitution. Magnús may have had the opportunity to rewrite his text once, filling in some of the detail in the narrative and clarifying certain elements - with the idea that he was writing for posterity. Magnús was rescuing from oblivion a story of poverty and injustice, along 


\section{LJÓS HEIMSINS}

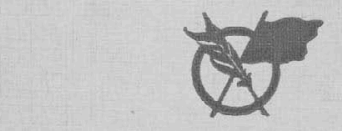

BÓKAÚTGÁFAN HEIMSKRINGLA

Figure 2 Cover of the book Ljós heimsins (in English World Light) by Halldór Kiljan Laxness

In the 1930s, about 15 years after the death of Magnús Hj. Magnússon, writer Halldór Kiljan Laxness published his novel Ljós heimsins (World Light), which is largely based upon Magnús' life story. He had made use of Magnús' diaries, and a remarkable amount of the content is reproduced, almost unchanged, in Laxness' novel. There is no doubt that Laxness made a thorough study of Magnús' life, his feelings and his character. Twenty years later (1956), an actual biography of Magnús was published by Gunnar M. Magnúss, a folk scholar from the same region of Iceland. A little more than 40 years after that book was published, in 1998 - the year of Laxness' death I published a selection of Magnús' works, from his diaries and his autobiography. Now, after a little more than 20 years, this book is published in English by Routledge, new information having come to light about important aspects of the life of the protagonist. The book focuses on the emotional experience of Magnús Hj. and the people around him.

National and University Library of Iceland. Photographer: Helgi Bragason 


\section{The normal exception}

with cultural heritage such as stories and rimes. Magnús' text must be judged in light of these factors; it embodies a man's feeling for life - the feeling of a man who has a lot to say - and a text which points to the way toward the kind of "emotional community" to which he belonged. ${ }^{8}$

Magnús' text, especially the elements relating to his emotionally fraught adventures, has previously been addressed by biographer Gunnar M. Magnúss in Skáldið á Pröm (The Poet from Pröm). ${ }^{9}$ The farm of Pröm was Magnús' last home. The book is a biography of Magnús, in which the author recounts the details of his life, making use of Magnús' many manuscripts. The principal flaw in Gunnar M. Magnúss' approach is a failure to differentiate clearly between his own narrative and Magnús' text; in places the reader loses sight of whether the biographer or his subject is speaking, and thus Gunnar's account of Magnús' often turbulent life sometimes fails to achieve the desired effect. Gunnar appears to have been too familiar with Magnús' life story - having known him well as a child - and the excitement and risk that typified Magnus' life is lost in the book.

Oddly, Gunnar M. Magnúss makes no reference at all in his book to Laxness' World Light, although it must have obvious to him, as to many others, that Laxness had made copious use of Magnús' diaries. And Skáldið á Pröm was published in 1956, shortly after Laxness had won the Nobel Prize for Literature! But in a interview in the magazine Utvarpsblaðið in 1951 Gunnar M. Magnúss gave the following account of Laxness' first acquaintance with Magnús' diaries:

Vilmundur, the Director of Public Health, had read a certain amount in the books he had owned [Vilmundur had acquired some of Magnús' books when he was Regional Physician at Ísafjörður, when they were auctioned off after his death along with other possessions] and perhaps more from that archive. One time when he met with Halldór Kiljan Laxness he pointed out the archive to him, and said: "Here you have the makings of a story."

Kiljan [Laxness] followed his suggestion, started to read the archive, and that process ended with his writing his novel about the Ljósvikingur, which is now well-known. ${ }^{10}$

Long before Halldór Kiljan Laxness and Gunnar M. Magnúss started to make use of Magnús' story and colorful life in their writing, another author, in the early 20th century, had observed how interesting a character

8 Barbara Rosenwein, Emotional Communities in the Early Middle Ages (Ithaca, NY: Cornell University Press, 2006). See discussions later in this book.

9 Gunnar M. Magnúss, Skáldið á Pröm. Ævisaga Magnúsar Hj. Magnússonar [The Poet from Pröm: A Biography] (Reykjavík: Iðunn, 1956).

10 “Ævisaga Ljósvíkings” [A Biography of a Poet], Útvarpsblaðið 1:15 (1951), p. 7. 
Magnús would be to write about. He was Sigurbjörn Sveinsson, a friend of Magnús and a fellow-writer, who is best known for his book Bernskan (Childhood), which was read by many Icelandic children well into the second half of the 20th century. In 1910-11, when Magnús was in jail in Reykjavík for the rape of a 14-year-old girl who was a former pupil (to which we shall return in the next part of the book), his friend Sigurbjörn made a point of visiting Magnús to cheer him up. In his diary Magnús writes about Sigurbjörn and their relationship:

he had it in mind to write a big novel, and he had already made a start; he talked of making me one of the main characters in the story - he said he found my life so "strange and interesting," and so he wanted to describe my way of thinking, my life's work and conditions of life, in so far as he could; and now he wanted my permission to do so. He also requested to borrow from me, for a fee, some of my diaries, in order to understand as well as possible my thinking at various times - but I could promise him nothing, as things stand. ${ }^{11}$

Before long Magnús gave Sigurbjörn permission to borrow the diary, with the following words: "He was welcome to it, but I probably would not have lent it to anyone else." 12 I do not know whether anything came of Sigurbjörn's planned novel, but Magnús may have been a model for some character(s) in Sigurbjörn's later writings. The inference is that from an early time Magnús' life and his diaries intrigued people who had some knowledge of him - and that is far from surprising, as the reader will have a chance to judge in this book.

The diary comprises 4,351 pages of quarto, in fine handwriting and containing exhaustive details of his daily toils over these years, along with reflections and poetry. The diary is of interest, not only because Magnús maintained it so scrupulously and used it to record his opinions, attitudes and feelings for people and animals, but because it reflects a life course that was constantly strewn with thorns. Magnús stood, in a sense, on the cusp between the old world and the new. There are aspects of his life that recall manners and customs that must strike modern readers as inconceivable. Despite all his adversities, Magnús appears in his diaries as a man who had a powerful desire to live a healthy, normal life, but was prevented from attaining that objective due to the prejudice and indifference he encountered regarding people in poverty. Magnús' unceasing efforts to live a life of dignity, recorded forthrightly in his diary, make this a document worth its weight in gold. Admittedly he made many mistakes and paid dearly for them, but that does not change the fact that he put great effort into living a life which could be viewed at first glance as morally decent and righteous.

11 Lbs 2228 4to - The Diary of Magnús Hj. Magnússon: 4 February 1912.

12 Lbs 2228 4to - The Diary of Magnús Hj. Magnússon: 11 February 1912. 


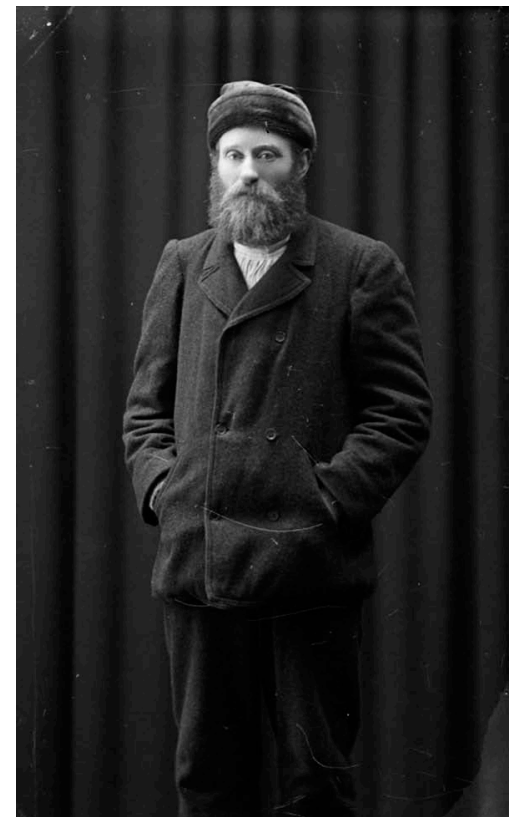

Figure 3 A self-portrait of Magnús Hj. Magnússon

"I know a man who is like this: He is nearly 70 inches tall, and quite thin for his height and rather narrow-waisted; he has long legs; a curved back; with high shoulders, with a neck of average length; with a small head; a fair mouth; with a largish nose, with a flat front or a disc on the front and a little kink in the middle. Rather heavy-browed, with light brows, grey-eyed, and with fine eyes - warm and bright. The tone of the face is usually rather white, but generally a fair color. He has a handsome face, is kindly and genial, and gentle-mannered, always kind and amiable and polite; is good at governing his temper, though he may occasionally fly into a rage, although it is hardly noticeable by others. He is quite drawn to women, though not obviously. He is an unusually sprightly walker, and quick in all his movements, but lacks stamina, which arises from his ill-health - although he is often surprisingly tenacious. - That man is: Magnús Hjaltason, who writes his name as Magnús Hj. Magnússon, since the summer of 1894. February 1898.” (Lbs 2216 4to - The Diary of Magnús Hj. Magnússon: Afterword 1898).

Ísafjörður Photo Archive no. 13192/1914. Photographer: Björn Pálsson

In childhood he had been raised in a foster family who received a stipend from the local authority for his keep, and his parents' poverty, along with his own ill-health and vulnerability, severely circumscribed his possibilities in life. The debt to the authorities, incurred in his youth as a pauper, followed him all his life; in later life he was refused permission to marry unless he settled the debt, which he was never able to do, and thus he lived "in sin" until death. He and his life-partner had six children, 
of whom only two lived to adulthood, as we shall see in the second part of the book. Ironically enough, Magnús' most treasured possessions - his diaries - were sold at auction after this death, in order to partially repay the debt to the authorities. So Magnús' record of the people with whom he had dealings finished up in the hands of those very men - until it was rescued and placed in the safekeeping of the National Library.

Magnús wrote a brief autobiographical sketch of his early years, almost until the time that he began to keep his diary at the age of 19. Magnús feels that he has been guided by principles of truth in his writing, and he articulates this idea well in the foreword to his autobiography:

I have as a rule in my writing wished to ensure that the side of truth should prevail, and I hope that this will be taken into account when judging what I have written, while taking less account of the personalities in question. To tell a false story is anathema to me. ${ }^{13}$

Magnús ends the foreword with his hopes for reception of the autobiography:

In hope of some gratitude from people of later times, I thus carry on my journey towards the work of a writer, which is subject to difficulties of various kinds, and I pray that the hand of the Almighty may sustain me in my work. ${ }^{14}$

Magnús thus appears to assume that his autobiography will find a readership; both the diary and the autobiography must be viewed in the context that Magnús was embarking upon his campaign for redress for the ill-treatment he had suffered in his youth.

Halldór Kiljan Laxness made extensive use of Magnús' voluminous diaries in writing his famous novel. Guðmundur Grímsson of Grunnavík, the scholar so admired by the pauper Jósep (see pp. 000-000) in the novel, was a composite of two real-life peasant scholars, Sighvatur Grímsson of Borgarfjörður and Pórður Pórðarson of Grunnavík, who were friends and allies of Magnús $\mathrm{Hj}$. The common factor shared by these three men, whose lives were reworked into Laxness' novel, was that they were all members of the class of people that historian Davíx Ólafsson and I have called

13 Sigurður Gylfi Magnússon, Kraftbirtingarhljómur Guðdómsins; see Lbs 2238 4to - Æfisaga Magnúsar Hjaltasonar. Rituð af sjálfum honum. Byrjuð á Suðureyri í Súgandafirði, 12. janúar 1914. [The Autobiography of Magnús Hjaltason].

14 Sigurður Gylfi Magnússon, Kraftbirtingarhljómur Guðdómsins; see Lbs 2238 4to - Æfisaga Magnúsar Hjaltasonar. Rituð af sjálfum honum. Byrjuð á Suðureyri í Súgandafirði, 12. janúar 1914. [The Autobiography of Magnús Hjaltason]. 


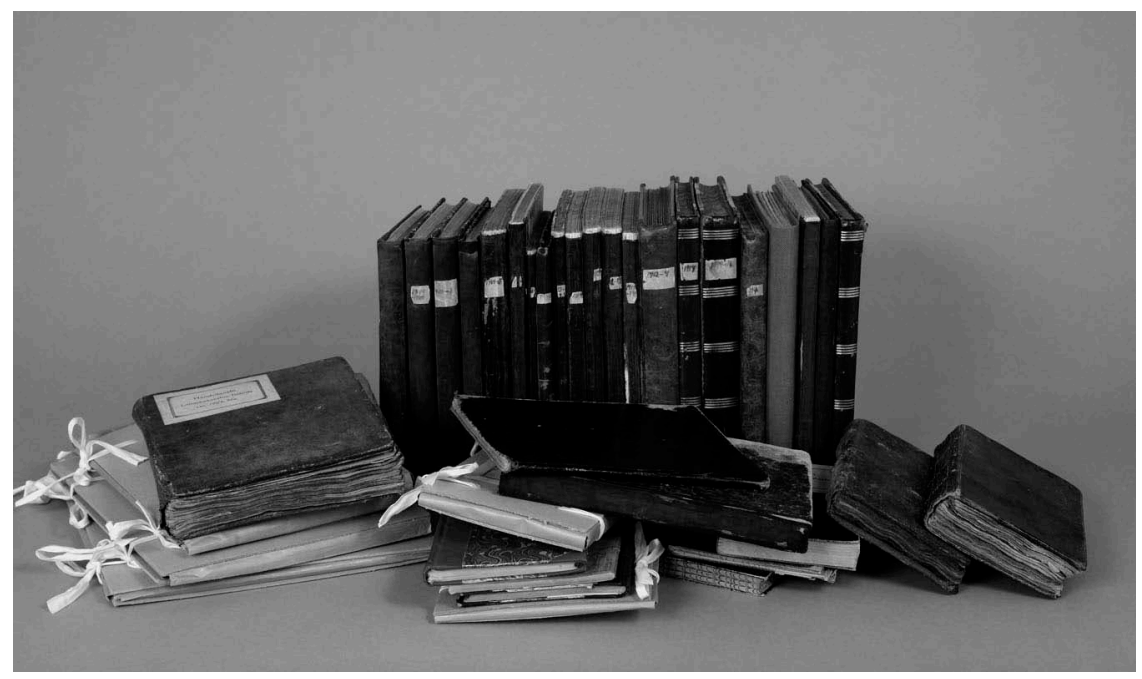

Figure 4 Manuscripts written by Magnús $\mathrm{Hj}$.

The diary of Magnús Hj. Magnússon fills 4,351 pages of quarto, in fine handwriting and containing exhaustive details of his daily toils over these years, along with reflections and poetry. The diary is of interest, not only because Magnús maintained it so scrupulously and used it to record his opinions, attitudes and feelings for people and animals, but because it reflects a life course that was constantly strewn with thorns. Magnús wrote also a brief autobiographical sketch of his early years, almost until the time that he began to keep his diary at the age of 19 . He composed verse all his life, and also compiled a range of interesting information gathered from others - either from oral accounts or copied from old manuscripts - some of them centuries old. The material he compiled in this way was wide-ranging, and opens an unusual perspective on the life of a poor man who had a passion for writing down everything he experienced and thought.

National and University Library of Iceland. Photographer: Helgi Bragason

"barefoot historians". ${ }^{15}$ That group was much more numerous - for instance in the West Fjords region alone in the 19th century. In the early years of the 20th century Magnús Hj. Magnússon compiled a list of over 200 men and women whom he knew to have engaged in poetry and literary pursuits. The list includes a number of nationally renowned and recognized poets, as well as officials and clerics with a talent for verse; but the

15 Sigurður Gylfi Magnússon and Davíð Ólafsson, "Barefoot Historians: Education in Iceland in the Modern Period", in Klaus-Joachim Lorenzen-Schmidt and Bjørn Poulsen, eds., Writing Peasant: Studies on Peasant Literacy in Early Modern Northern Europe (Kerteminde: Landbohistorisk Selskab, 2002), pp. 175-209. See also Sigurður Gylfi Magnússon and Davíð Ólafsson, Minor Knowledge and Microhistory, in which the relationship between the men is explored in detail. 
majority of the poets and lay scholars were members of the numerous class of self-taught peasants who are, in part, the subject of this book. Magnús generally referred to such individuals in Icelandic as skáldyrðingar, a term that may be expressed in English as something like "poet-scholar". ${ }^{16}$ The word skáldyrðingur, coined by Magnús, is an unusually potent neologism, embracing the pursuits of many of the people listed: they enthusiastically transcribed manuscripts, and in between times they wrote verse or collected poems - they had verse continually on their lips, like many others around them. The distinction generally drawn today between poets and writers on the one hand, and scholars on the other, does not play a big part in the mindset of people like Magnús $\mathrm{Hj}$. Magnússon. He alone, for instance, left 11,000 poems and rimur (rimes). In other words, he wrote about three of these every day of his life - and many were long and complex! But his activity was far from unique in the West Fjords. Sighvatur Grímsson, for example, compiled biographies of all Iceland's priests and clergy from the time of the settlement in the 9th century until the end of the 19th. The text, which is about 20,000 pages in length, is one of the most valued bases for genealogical research in Iceland. ${ }^{17}$ In addition Sighvatur kept a detailed diary for 67 years, in which he noted, among other things, all his literary activity and other notable events. Sighvatur was a farmer who lived most of his life in dire poverty on the farm of Höfði in Dýrafjörður in the West Fjords - the same region where Magnús spent almost all his life. These men formed an "emotional community" of a kind in the West Fjords - a community which provided those who needed it with a mental refuge - and also a tangible one, as a man like Magnús $\mathrm{Hj}$. would often seek support from some other member of the group, as he knew that he would always be given shelter, at least for a time.

16 Lbs 2235 4to - Gríma: Skáld og hagyrðingar á Íslandi 1902-1903. [The Work of Magnús Hj. Magnússon].

17 See Davíð Ólafsson's doctoral thesis: Wordmongers: Post-Medieval Scribal Culture and the Case of Sighvatur Grimsson, Ph.D. thesis, University of St Andrews, Scotland, 2008. 


\section{Bibliography}

\section{Manuscripts and archival material}

Lbs 2216-2234 4to - The Diary of Magnús Hj. Magnússon.

Lbs 2235 4to - Gríma: Skáld og hagyrðingar á Íslandi 1902-1903.

Lbs 2238 4to - Æfisaga Magnúsar Hjaltasonar. Rituð af sjálfum honum. Byrjuð á Suðureyri í Súgandafirði, 12. janúar 1914.

P.Í. Skjalasafn Landsyfirréttar - Askja nr. 196. Ár 1911. Málsskjöl XVII-XXIX.

\section{Interviews}

Sigurður Gylfi Magnússon with scholar and former editor Kjartan Ólafsson, March 1998. Kjartan's roots are in Súgandafjörður, and he is very well-informed about life in the West Fjords in past and present.

Sigurður Gylfi Magnússon with Ásta S. Reynis, October 1998.

\section{Published works}

Ankersmit, Frank. "Remembering the Holocaust: Mourning and Melancholia", in Anne Ollila, ed. Historical Perspectives on Memory (Helsinki: SHS, 1999), pp. 91-113.

Appuhn, Karl. "Microhistory”, in Peter N. Stearns, ed. The Encyclopaedia of European Social History I (New York: Scribner, 2001), pp. 105-112.

Ariès, Philippe. Centuries of Childhood: A Social History of Family Life. Trans. Robert Baldick (London: Random House, 1965).

Aurell, Jaume. "Making History by Contextualizing Oneself: Autobiography as Historiographical Intervention”, History and Theory 54 (May 2015), pp. 244-268.

Averill, James R. "The Functions of Grief”, in Carroll E. Izard, ed. Emotions in Personality and Psychopathology (New York: Springer Dordrecht, 1979), pp. 339-368.

Barret-Ducrocq, Françoise. Love in the Time of Victoria. Trans. John Howe (London: Penguin Books, 1991).

Bell, Michael and Sze Tsung Leong, eds. Slow Space (New York: Monaccelli Press, 1998).

Bell, Rudolph M., and Judith C. Brown. "Renaissance Sexuality and the Florentine Archives: An Exchange”, Renaissance Quarterly 40 (1987), pp. 485-511. 
Berenson, Edward. "The Politics of Divorce in France of the Belle Epoque: The Case of Joseph and Henrietta Caillaux", American Historical Review 93 (1988), pp. 31-55.

Berenson, Edward. The Trial of Madame Caillaux (Berkeley and Los Angeles: University of California Press, 1992).

Black, Cyril E., et al. The Modernization of Japan and Russia (New York: Free Press, 1975).

Braembussche, Antoon van den. "The Politics of Time: Reflections on Time, Memory and History", in Anne Ollila, ed. Historical Perspectives on Memory (Helsinki: SHS, 1999), pp. 171-193.

Bragadóttir, Kristín. Íslenskar bœekur erlendis. Bókasöfnun Willards Fiskes (1831-1904), Ph.D. dissertation, University of Iceland, 2017.

Brewer, John. A Sentimental Murder: Love and Madness in the Eighteenth Century (New York: Farrar, Straus and Giroux, 2004).

Brooks, James F., Christopher R.N. DeCorse and John Walton, eds. Small Worlds: Methods Meaning and Narrative in Microhistory (Santa Fe: School for Advanced Research Press, 2008).

Brown, Judith C. Immodest Acts: The Life of a Lesbian Nun in Renaissance Italy (New York: Oxford University Press, 1986).

Brown, Richard D. "Microhistory and the Post-Modern Challenge", Journal of the Early Republic 23:1 (2003), pp. 1-20.

Brucker, Gene. Giovanni and Lusanna: Love and Marriage in Renaissance Florence (Berkeley: University of California Press, 1986).

Burns, Robert M., ed. Historiography: Critical Concepts in Historical Studies, Vols I-V (London: Routledge, 2006), in vol. IV: Cultural History.

Cahn, Susan K. Coming on Strong: Gender and Sexuality in Twentieth-Century Women's Sport (New York: Free Press, 1994).

Carr, David. Experience and History: Phenomenological Perspectives on the Historical World (Oxford: Oxford University Press, 2014).

Castrén, Anna-Maija, Karkku Lonkila and Matti Peltonen, eds. Between Sociology and History: Essays on Microhistory, Collective Action, and Nation-Building (Helsinki: Suomalaisen Kirjallisuuden Seura, 2004).

Cipolla, Carlo M. Faith, Reason, and the Plague in Seventeenth-Century Tuscany (Ithaca, NY: Cornell University Press, 1979).

Clark, Anna. "Queen Caroline and the Sexual Politics of Popular Culture in London, 1820", Representations 31 (Summer 1990), pp. 47-68.

Cohen, Patricia Cline, The Murder of Helen Jewett: The Life and Death of a Prostitute in Nineteenth-Century New York (New York: Vintage Books, 1998).

Cohen, Thomas V. Roman Tales: A Reader's Guide to the Art of Microhistory (London: Routledge, 2019).

Confino, Alon. "AHR Forum: Collective Memory and Cultural History: Problems of Method", American Historical Review 102 (December 1997), pp. 1386-1403.

Connerton, Paul. How Societies Remember (Cambridge: Cambridge University Press, 1989).

Cook, Harold J. The Trials of an Ordinary Doctor: Joannes Groenevelt in Seventeenth-Century London (Baltimore: Johns Hopkins University Press, 1994).

Corbin, Alain. The Village of Cannibals: Race and Murder in France, 1870. Trans. Arthur Goldhammer (Cambridge, MA: Harvard University Press, 1992). 
Crane, Susan A. "AHR Forum: Writing the Individual Back into Collective Memory”, American Historical Review 102 (December 1997), pp. 1372-1385.

Dahlstedt, Kristín, veitingakona. Endurminningar. Hafliði Jónsson frá Eyrum skráði (Reykjavík: Bókaútgáfan Muninn, 1961).

Darnton, Robert. The Great Cat Massacre and Other Episodes in French Cultural History (New York: Cornell University Press, 1984).

Davis, Natalie Zemon. The Return of Martin Guerre (Cambridge, MA: Harvard University Press, 1983).

Davis, Natalie Zemon. "Who Owns History?" in Anne Ollila, ed. Historical Perspectives on Memory (Helsinki: SHS, 1999), pp. 19-34.

D'Emilio, John. "The History of Sexuality: An Assessment of the State of the Field", History and Theory 58:1 (2019), pp. 126-134.

D'Emilio, John, and Estelle B. Freedman. Intimate Matters: A History of Sexuality in America (New York: Harper \& Row, 1989).

Duberman, Martin, Martha Vicinus and George Chauncey, eds. Hidden from History: Reclaiming the Gay and Lesbian Past (New York: Penguin Books, 1989).

Duggan, Lisa. "The Trials of Alice Mitchell: Sensationalism, Sexology and the Lesbian Subject in Turn-of-the-Century America”, Signs 18 (Summer 1993), pp. 791-814.

Eder, Franz X., Lesley A. Hall and Gert Hekma. Sexual Cultures in Europe: National Histories (Manchester: Manchester University Press, 1999).

Eder, Franz X., Lesley A. Hall and Gert Hekma. Sexual Cultures in Europe: Themes in Sexuality (Manchester: Manchester University Press, 1999).

Egmond, Florike, and Peter Mason. The Mammoth and the Mouse: Microhistory and Morphology (Baltimore: Johns Hopkins University Press, 1997).

Eley, Geoff. "Labor History, Social History, Alltagsgeschichte: Experience, Culture, and the Politics of the Everyday. A New Direction for German Social History?" Journal of Modern History 61 (June 1989), pp. 297-343.

Fentress, James, and Chris Wickham. Social Memory (Oxford: Blackwell, 1992).

Flandrin, Jean-Louis. Families in Former Times: Kinship, Household and Sexuality. Trans. Richard Southern (Cambridge: Cambridge University Press, 1979).

Foucault, Michel. The History of Sexuality I. An Introduction. Trans. Robert Hurley (London: Penguin Books, 1990).

Freedman, Estelle B. The History of the Family and the History of Sexuality. The New American History Series (Washington, DC: American Historical Association, 1997).

Frisch, Michael. "American History and the Structures of Collective Memories: A Modest Exercise in Empirical Iconography", Journal of American History 76 (1989), pp. 1130-1155.

Fuchs, Rachel G. Poor and Pregnant in Paris: Strategies for Survival in the Nineteenth Century (New Brunswick: Rutgers University Press, 1992).

Garðarsdóttir, Ólöf. Saving the Child: Regional, Cultural and Social Aspects of the Infant Mortality Decline in Iceland, 1770-1920 (Umeå: Umeå University Press, 2002), pp. 49-105.

Gedi, Noa, and Yigal Elam. "Collective Memory-What Is It?" History and Memory 8 (Spring/Summer 1996), pp. 30-50.

Ginzburg, Carlo. The Cheese and the Worms: The Cosmos of a Sixteenth-Century Miller (Baltimore and London: Johns Hopkins University Press, 1980).

Ginzburg, Carlo. "Microhistory: One or Two Things I Know About It", Critical Inquiry 20 (1993), pp. 10-35. 
Ginzburg, Carlo, and Carlo Poni. "The Name and the Game: Unequal Exchange and the Historical Marketplace”, in Edward Muir and Guido Ruggiero, eds. Microhistory and the Lost People of Europe. Trans. Eren Branch (Baltimore: Johns Hopkins University Press, 1991), pp. 1-10.

Gissurarson, Hannes Hólmsteinn. Halldór. Ævisaga Halldórs Kiljans Laxness 1902-1932 (Reykjavík: Almenna Bókafélagið, 2003).

Graff, Harvey J. "History's War of the Wor(l)ds", in Sigurður Gylfi Magnússon, Sögustríð. Greinar og frásagnir um bugmyndafræeði (Reykjavík: Center for Microhistorical Research, 2007), pp. 475-481.

Grethlein, Jonas. "Experience and History: The Reach and Limits of Phenomenological Approaches to History", History and Theory 58 (June 2019), pp. 302-321.

Grew, Raymond. "More on Modernization”, Journal of Social History 14 (1980), pp. 179-187.

Guðmundsson, Halldór. "Skrýtnastur er maður sjálfur. Um minningasögur Halldór Laxness”, Tímarit Máls og menningar 53:3 (1992), pp. 20-30.

Gunnarsdóttir, Sigprúður. "Leitin að upptökum Nílar. Um minningabækur Halldórs Laxness", Tímarit Máls og menningar 59:2 (1998), pp. 81-95.

Gunnlaugsson, Gísli Ágúst. Family and Household in Iceland 1801-1930: Studies in the Relationship Between Demographic and Socio-Economic Development, Social Legislation and Family and Household Structures (Uppsalir: Acta Universitatis Upsaliensis, 1988).

Haan, Binne de, and Kostantin Mierau, eds. Microhistory and the Picaresque Novel: A First Exploration into Commensurable Perspectives (London: Cambridge Scholars Publishing, 2014).

Halbwachs, Maurice. On Collective Memory (Chicago: University of Chicago Press, 1992 [1914]).

Halldórsdóttir, Erla Hulda. "Fragments of Lives: The Use of Private Letters in Historical Research", NORA. Nordic Journal of Women's Studies 15:1 (2007), pp. 35-49.

Hallgrímsdóttir, Guðný. Sagan af Guðrúnu Ketilsdóttur. Einsögurannsókn á aevi 18. aldar vinnukonu, Sýnisbók íslenskrar albýðumenningar 16 (Reykjavík: Háskólaútgáfan, 2013).

Hallgrímsdóttir, Guðný. A Tale of a Fool? A Microhistory of an 18th-Century Peasant Woman (London: Routledge, 2019).

Hitchcock, Tim, and Robert Shoemaker. Tales from the Hanging Court (London: Bloomsbury Academic, 2006).

Hutton, Patrick. History as an Art of Memory (Hanover and London: University Press of New England, 1993).

Hutton, Patrick. "Mentalities, Matrix of Memory", in Anne Ollila, ed. Historical Perspectives on Memory (Helsinki: SHS, 1999), pp. 69-90.

Iggers, Georg G. "The Role of Professional Historical Scholarship in the Creation and Distortion of Memory", in Anne Ollila, ed. Historical Perspectives on Memory (Helsinki, 1999), pp. 49-67.

Inkeles, Alex, and David H. Smith. Becoming Modern: Individual Change in Six Developing Countries (Cambridge, MA: Harvard University Press, 1974).

Jones, Gareth Stedman. Languages of Class: Studies in English Working Class History 1832-1982 (Cambridge: Cambridge University Press, 1983).

Jónsson, Guðmundur. Vinnubjú á 19. öld. Ritsafn Sagnfræðistofnunar 5 (Reykjavík: Sagnfræðistofnun Háskóla Íslands, 1981). 
Jónsson, Jón, and Sigurður Gylfi Magnússon. "Heimskuleg spurning fær háðulegt svar. Orð og æði - Minni og merking”, Íslenska sögupingið 28.- 31. maí 1997. Ráðstefnurit II (Reykjavík, 1998), pp. 49-52.

Kalb, D., and H. Tak, eds. Critical Junctions: Anthropology and History Beyond the Cultural Turn (London: Berghahn Books, 2005).

Kammen, Michael. The Mystic Chords of Memory (New York: Knopf, 1991).

King, Margaret L. The Death of the Child Valerio Marcello (Chicago: University of Chicago Press, 1994).

Kingdon, Robert M. Adultery and Divorce in Calvin's Geneva (Cambridge, MA: Harvard University Press, 1995).

Kristjánsson, Gunnar. "Úr heimi Ljósvíkingsins", Tímarit Máls og menningar 43:1 (1982), pp. 9-36.

Kuehn, Thomas. "Reading Microhistory: The Example of Giovanni and Lusanna", Journal of Modern History 61 (1989), pp. 512-534.

Ladurie, Emmanuel Le Roy. Montaillou: The Promised Land of Error. Trans. Barbara Bray (New York: George Braziller, 1978).

Landsyfirréttardómar og hostaréttardómar i islenzkum málum. VIII. Bindi 1908-1912 (Reykjavík: Ísafoldarprentsmiðja, 1913).

Laqueur, Thomas. Making Sex: Body and Gender from the Greeks to Freud (Cambridge, MA: Harvard University Press, 1990).

Laxness, Halldór Kiljan. Skáldatími (Reykjavík: Helgafell, 1963).

Laxness, Halldór Kiljan. World Light. Trans. from the Icelandic by Magnús Magnússon (New York: Vintage International, 2002).

Levi, Giovanni. “On Microhistory”, in Peter Burke, ed. New Perspectives on Historical Writing (University Park: Pennsylvania State University Press, 1991), pp. 93-113.

Levine, Robert. A Geography of Time: The Temporal Misadventures of a Social Psychologist, or How Every Culture Keeps Time Just a Little Bit Differently (New York: Basic Books, 1997).

Levy Jr., Marion J. Modernization and the Structure of Societies (Princeton: Princeton University Press, 1966).

Liliequist, Jonas. "Peasants against Nature: Crossing the Boundaries between Man and Animal in Seventeenth- and Eighteenth-Century Sweden", Journal of the History of Sexuality 1 (1991), pp. 393-423.

Lofland, Lyn H. "The Social Shaping of Emotion: The Case of Grief”, Symbolic Interaction 8 (1985), pp. 171-190.

Lowenthal, David. "Fabricating History”, History and Memory 10 (1998), pp. 5-24.

Lowenthal, David. The Past Is a Foreign Country (Cambridge: Cambridge University Press, 1985).

Lüdtke, Alf. "Introduction: What is the History of Everyday Life and Who are its Practitioners?" in Alf Lüdtke, ed. The History of Everyday Life: Reconstructing Historical Experiences and Ways of Life. Trans. William Templer (Princeton: Princeton University Press, 1995).

Lüdtke, Alf. “Organizational Order or Eigensinn? Workers' Privacy and Workers' Politics in Imperial Germany", in Sean Wilentz, ed. Rites of Power: Symbolism, Ritual, and Politics Since the Middle Ages (Philadelphia: University of Pennsylvania Press, 1985), pp. 303-333.

Lüdtke, Alf. "What Happened to the 'Fiery Red Glow'? Workers' Experiences and German Fascism”, in Alf Lüdtke, ed. The History of Everyday Life: Reconstructing 
Historical Experiences and Ways of Life. Trans. William Templer (Princeton: Princeton University Press, 1995), pp. 198-251.

Lystra, Karen. Searching the Heart: Women, Men, and Romantic Love in Nineteenth-Century America (New York: Oxford University Press, 1989).

Magnúsardóttir, Lára. "Íslendingar á 18. öld: um veraldlegar hliðar mannlífsins”, Ný saga 6 (1993), pp. 70-81.

Magnúss, Gunnar M. Ósagðir hlutir um skáldið á Pröm (Hafnarfjörður: Skuggsjá, 1973).

Magnúss, Gunnar M. Skáldið á Pröm. Ævisaga Magnúsar Hj. Magnússonar (Reykjavík: Iðunn, 1956).

Magnússon, Guðgeir. “'Рað er margt í bókunum ...' Viðtal við ekkju alpýðuskálds”, Birtingur 2 (1956), pp. 1-9.

Magnússon, Magnús S. Iceland in Transition: Labour and Socio-Economic Change Before 1940 (Lund: Ekonomisk-historiska föreningen, 1985).

Magnússon, Sigurður Gylfi. “Albýðumenning á Íslandi, 1850-1940”, in Guðmundur Hálfdanarson and Svanur Kristjánsson, eds. Íslensk pjóðfélagspróun 1880-1990: Ritgerðir (Reykjavík: Háskólaútgáfan, 1993), pp. 265-320.

Magnússon, Sigurður Gylfi. The Continuity of Everyday Life: Popular Culture in Iceland 1850-1940. Ph.D. dissertation, Carnegie Mellon University, USA, 1993.

Magnússon, Sigurður Gylfi. Fortiðardraumar: Sjálfsbókmenntir á Íslandi. Sýnisbók íslenskrar albýðumenningar 9 (Reykjavík: Háskólaútgáfan in collaboration with the Center for Microhistorical Research, 2004).

Magnússon, Sigurður Gylfi. "From Children’s Point of View: Childhood in Nineteenth Century Iceland”, Journal of Social History 29 (Winter 1995), pp. 295-323.

Magnússon, Sigurður Gylfi, ed. Kraftbirtingarhljómur Guðdómsins: Dagbók, sjálfsavisaga, bréf og kvœði Magnúsar Hj. Magnússonar skáldsins á Pröm. Sýnisbók íslenskrar albýðumenningar 2 (Reykjavík: Háskólaútgáfan, 1998).

Magnússon, Sigurður Gylfi. "The Life is Never Over: Biography as a Microhistorical Approach", in Hans Renders, Binne De Haan and Jonne Harmsma, eds. The Biographical Turn: Lives in History (London: Routledge, 2017), pp. 42-52.

Magnússon, Sigurður Gylfi. "The Love Game as Expressed in Ego-Documents: The Culture of Emotions in Late Nineteenth Century Iceland", Journal of Social History 50:1 (2016), pp. 102-119.

Magnússon, Sigurður Gylfi. Menntun, ást og sorg: Einsögurannsókn á íslensku sveitasamfélagi 19. og 20. aldar, Sagnfræðirannsóknir 13 (Reykjavík: Sagnfræðistofnun Háskóla Íslands og Háskólaútgáfan, 1997).

Magnússon, Sigurður Gylfi. "Microhistory, Biography and Ego-Documents in Historical Writing”, Revue d'histoire Nordique 20 (2016), pp. 133-153.

Magnússon, Sigurður Gylfi. “The Singularization of History: Social History and Microhistory within the Postmodern State of Knowledge", Journal of Social History 36 (Spring 2003), pp. 701-735.

Magnússon, Sigurður Gylfi. "Social History as 'Sites of Memory’? The Institutionalization of History: Microhistory and the Grand Narrative", Journal of Social History special issue 39:3 (Spring 2006), pp. 891-913.

Magnússon, Sigurður Gylfi. Sjálfssögur: minni, minningar og saga. Sýnisbók íslenskrar albýðumenningar 11 (Reykjavík: Háskólaútgáfan in collaboration with the Center for Microhistorical Research, 2005).

Magnússon, Sigurður Gylfi. "Sögur af fátæku fólki og purfalingunum árið 1902”, in Jón Ólafur Ísberg and Sigurður Gylfi Magnússon, eds. Fátcekt og fúlga: Purfalingarnir 
1902. Sýnisbók íslenskrar albýðumenningar 19 (Reykjavík: Háskólaútgáfan, 2016), pp. 37-150.

Magnússon, Sigurður Gylfi. Sögustríð. Greinar og frásagnir um hugmyndafræeði (Reykjavík: Center for Microhistorical Research, 2007).

Magnússon, Sigurður Gylfi. Spánar kóngurinn. Ástarsaga (Reykjavík: Center for Microhistorical Research, 2009).

Magnússon, Sigurður Gylfi. “Tales of the Unexpected: The 'Textual Environment', Ego-Documents and a Nineteenth-Century Icelandic Love Story - An Approach in Microhistory", Cultural and Social History 12:1 (2015), pp. 77-94.

Magnússon, Sigurður Gylfi. "Views into the Fragments: An Approach from a Microhistorical Perspective", International Journal of Historical Archaeology 20 (2016), pp. 182-206.

Magnússon, Sigurður Gylfi. Wasteland with Words: A Social History of Iceland (London: Reaktion Books, 2010).

Magnússon, Sigurður Gylfi, and Davíð Ólafsson. "Barefoot Historians: Education in Iceland in the Modern Period", in Klaus-Joachim Lorenzen Schmidt and Bjørn Poulsen, eds. Writing Peasant: Studies on Peasant Literacy in Early Modern Northern Europe (Kerteminde: Landbohistorisk Selskab, 2002), pp. 175-209.

Magnússon, Sigurður Gylfi, and Davíð Ólafsson. Minor Knowledge and Microhistory: Manuscript Culture in the Nineteenth Century (London: Routledge, 2017).

Magnússon, Sigurður Gylfi, and István M. Szijártó. What is Microhistory? Theory and Practice (London: Routledge, 2013).

Martin, John. "Journeys to the World of the Dead: The Work of Carlo Ginzburg", Review essay, Journal of Social History 25 (Spring 1992), pp. 613-626.

Mascuch, Michael, Rudolf Dekker and Arianne Baggerman. "Egodocuments and History: A Short Account of the Long Durée”, The Historian (2016), pp. 11-56.

McDonald, T.J., ed. The Historic Turn in the Human Sciences (Ann Arbor, MI: University of Michigan Press, 1996).

McLaren, Angus. A Prescription for Murder: The Victorian Serial Killings of Dr. Thomas Neill Cream (Chicago: University of Chicago Press, 1993).

McLaren, Angus. Sexual Blackmail: A Modern History (Cambridge, MA: Harvard University Press, 2002).

"Memory and Counter Memory", special issue of Representations 26 (Spring 1989). Edited by Natalie Zemon Davis and Randolph Starn.

Middleton, David, and Derek Edwards, eds., Collective Remembering (London: Sage Publications, 1990).

Mímisson, Kristján, and Sigurður Gylfi Magnússon, "Singularizing the Past: The History and Archaeology of the Small and Ordinary", Journal of Social Archaeology 14:2 (2014), pp. 131-156.

Molho, Anthony. "Gene Brucker. Giovanni and Lusanna: Love and Marriage in Renaissance Florence”, Review, Renaissance Quarterly 40 (1987), pp. 96-100.

Monod, Paul Kléber. The Murder of Mr. Grebell: Madness and Civility in an English Town (New Haven: Yale University Press, 2003).

Muir, Edward. "Clues, Myths, and the Historical Method: By Carlo Ginzburg", Review, Journal of Social History 25 (Fall 1991), pp. 123-125.

Muir, Edward. "Introduction: Observing Trifles", in Edward Muir and Guido Ruggiero, eds. Microhistory and the Lost People of Europe. Trans. Eren Branch (Baltimore: Johns Hopkins University Press, 1991), pp. vii-xxviii. 
Muir, Edward, and Guido Ruggiero, eds. History from Crime. Trans. Corrada Biazzo Curry, Margaret A. Gallucci and Mary M. Gallucci (Baltimore: Johns Hopkins University Press, 1994).

Muir, Edward, and Guido Ruggiero, eds. Sex and Gender in Historical Perspective. Trans. Margaret A. Gallucci with Mary M. Gallucci and Carole C. Gallucci (Baltimore: Johns Hopkins University Press, 1990).

Nora, Pierre. "Between Memory and History: Les Lieux de Mémoire", Representations 26 (Spring 1989), pp. 7-25.

Nussbaum, Martha C. Upheavals of Thought: The Intelligence of Emotions (Cambridge: Cambridge University Press, 2001).

Oatley, Keith. Emotions: A Brief History (Oxford: Blackwell, 2004).

Ólafsson, Davíð. “Að skrá sína eigin tilveru. Dagbækur, sjálfsmynd og heimsmynd á 18. og 19. öld”, in Erla Hulda Halldórsdóttir and Sigurður Gylfi Magnússon, eds. Einsagan - ólíkar leiðir. Átta ritgerðir og eitt myndlistarverk (Reykjavík: Háskólaútgáfan, 1998), pp. 51-88.

Ólafsson, Davíð. "Vernacular Literacy Practices in Nineteenth-Century Icelandic Scribal Culture", in Ann-Catrine Edlund, ed. Att läsa och att skriva: Två vågor av vardagligt skriftbruk $i$ Norden 1800-2000. Nordliga studier 3 (Umeå: Umeå Universitet og Kungl. Skytteanska Samfundet, 2012), pp. 65-85.

Ólafsson, Davíð. Wordmongers: Post-Medieval Scribal Culture and the Case of Sighvatur Grimsson, Ph.D. thesis, University of St Andrews, Scotland, 2008.

Ólafsson, Davío. Wordmongers: Post-Medieval Scribal Culture and the Case of Sighvatur Grimsson. Forthcoming from Cornell University Library in the book series Islandica, 2020.

Ollila, Anne. "Introduction: History as Memory and Memory as History", in Anne Ollila, ed. Historical Perspectives on Memory (Helsinki: SHS, 1999), pp. 7-18.

Ozment, Steven. The Bürgermeister's Daughter: Scandal in a Sixteenth-Century German Town (New York: St. Martin's Press, 1996).

Ozment, Steven. Magdalena and Balthasar: An Intimate Portrait of Life in 16thCentury Europe Revealed in the Letters of a Nuremberg Husband and Wife (New Haven: Yale University Press, 1989).

Peiss, Kathy, Christine Simmons and Robert A. Padgug, Passion and Power: Sexuality in History (Philadelphia: Temple University Press, 1989).

Peltonen, Matti."Clues, Margins and Monads: The Micro-Macro Link in Historical Research", History and Theory 40 (2001), pp. 347-359.

Plamper, Jan. "The History of Emotions: An Interview with William Reddy, Barbara Rosenwein, and Peter Stearns", History and Theory 49 (May 2010), pp. 237-265.

Pollock, Linda A. Forgotten Children: Parent-Child Relationship from 1500 to 1900 (New York and Cambridge: Cambridge University Press, 1983).

Ponsonby, Arthur. English Diaries: A Review of English Diaries from the Sixteenth to the Twentieth Century with an Introduction on Diary Writing (London: Methuen \& Co., 1923).

Pucci, Idanna. The Trials of Maria Barbella: The True Story of a 19th-Century Crime of Passion (New York: Basic Books, 1996).

Reddy, William M. "Emotional Styles and Modern Forms of Life", in Nicole Karafyllis and Gotling Ulshöfer, eds. Sexualized Brains: Scientific Modeling of Emotional Intelligence from a Cultural Perspective (Cambridge, MA: MIT Press, 2008), pp. 81-100. 
Reddy, William M. The Making of Romantic Love: Longing and Sexuality in Europe, South Asia and Japan, 900-1200 ce (Chicago: University of Chicago Press, 2012).

Reddy, William M. The Navigation of Feeling: A Framework for the History of Emotions (Cambridge: Cambridge University Press, 2001).

Rethinking History 13:1 (March 2009), pp. 1-108.

Rosenwein, Barbara H. Emotional Communities in the Early Middle Ages (Ithaca, NY: Cornell University Press, 2006).

Rosenwein, Barbara H. Generations of Feeling: A History of Emotions, 6001700 (Cambridge: Cambridge University Press, 2016).

Rosenwein, Barbara H. "Problems and Methods in the History of Emotions", Passions in Context: International Journal for the History and Theory of Emotions [online journal] 1 (2010). www.passionsincontext.de, accessed 5 December 2013.

Rosenwein, Barbara H. "Review Essay: Worrying about Emotions in History", American Historical Review 107 (June 2002), pp. 821-845.

Rosenwein, Barbara H., and Riccardo Cristiani. What is the History of Emotions? (London: Polity Press, 2018).

Rotundo, Anthony. American Manhood: Transformation in Masculinity from the Revolution to the Modern Era (New York: Basic Books, 1993).

Rozman, Gilbert, ed. The Modernization of China (New York: Free Press, 1980).

Ruggiero, Guido. Binding Passions: Tales of Magic, Marriage, and Power at the End of the Renaissance (New York: Oxford University Press, 1993).

Ruggiero, Guido. The Boundaries of Eros: Sex Crime and Sexuality in Renaissance Venice (Oxford: Oxford University Press, 1985).

Samuel, Raphael. Theatres of Memory (London: Verso, 1994).

Schuman, Howard, and Jacqueline Scott. "Generations and Collective Memories", American Sociological Review 54 (June 1989), pp. 359-381.

Scott, Joan W. "The Evidence of Experience”, Critical Inquiry 17:4 (Summer 1991), pp. 773-797.

Scott, Joan W. "History-Writing as Critique”, in K. Jenkins, S. Morgan and A. Munslow, eds. Manifestos for History (London: Routledge, 2007), pp. 19-38.

Seidman, Steven. Romantic Longings: Love in America, 1830-1980 (New York: Routledge, 1993).

Sherr, Richard. "A Canon, a Choirboy, and Homosexuality in Late Sixteenth Century Italy: A Case Study”, Journal of Homosexuality 21 (1991), 1-22.

Shorter, Edward. The Making of the Modern Family (New York: Basic Books, 1975).

Sigel, Lisa Z. Governing Pleasures: Pornography and Social Change in England 1815-1914 (New Brunswick: Rutgers University Press, 2002), pp. 1-14.

Sigel, Lisa Z. "Sexual Behavior and Sexual Morality", Encyclopedia of European Social History: From 1350 to 2000. Vol. 4. Editor in chief Peter N. Stearns (New York: Scribner, 2001), pp. 243-258.

Sigurðsson, Gísli. "Pjóðsögur", Íslensk bókmenntasaga III. Edited by Halldór Guðmundsson (Reykjavík: Mál og menning, 1996).

Smith-Rosenberg, Carroll. Disorderly Conduct: Visions of Gender in Victorian America (New York: Alfred A. Knopf, 1985).

Slow Space. Edited by Michael Bell and Sze Tsung Leong (New York: Monacelli Press, 1998). 
Sohn, Anne-Marie. "Illegitimacy and Concubinage", Encyclopedia of European Social History. From 1350 to 2000. Vol. 4. Editor in chief Peter N. Stearns (New York: Scribner, 2001), pp. 259-267.

Srebnick, Amy Gilman. The Mysterious Death of Mary Rogers: Sex and Culture in Nineteenth-Century New York (New York: Oxford University Press, 1995).

Stearns, Carol Z."'Lord Help Me Walk Humbly': Anger and Sadness in England and America, 1570-1750", in Carol Z. Stearns and Peter N. Stearns, eds. Emotion and Social Change: Toward a New Psychohistory (New York: Lynne Rienner, 1988), pp. 39-68.

Stearns, Peter N. "Debates About Social History and its Scope", in Sigurður Gylfi Magnússon, Sögustrið. Greinar og frásagnir um hugmyndafræði (Reykjavík: Center for Microhistorical Research, 2007), pp. 17-21.

Stearns, Peter N. "History of Emotions: Issues of Change and Impact", in Michael Lewis, Jeannette M. Haviland-Jones and Lisa Feldman Barrett, eds. Handbook of Emotions, 3rd edn (New York: Guilford Press, 2008), pp. 17-31.

Stearns, Peter N. "Modernization", Encyclopedia of European Social History: From 1350 to 2000. Volume 2. Editor in chief Peter N. Stearns (New York: Scribner, 2001), pp. 3-12.

Stearns, Peter N. "Modernization and Social History: Some Suggestions, and a Muted Cheer", Journal of Social History 14 (Winter 1980), pp. 189-209.

Stearns, Peter N., and Timothy Haggerty. "The Role of Fear: Transitions in American Emotional Standards for Children, 1850-1950”, American Historical Review 96:1 (1991), pp. 63-94.

Stearns, Peter N., and Jan Lewis, eds. An Emotional History of the United States (New York: New York University Press, 1998).

Stearns, Peter N., and Carol Stearns. Anger: The Struggle for Emotional Control in America's History (Chicago: University of Chicago Press, 1986).

Stearns, Peter N., and Carol Stearns. "Emotionology: Clarifying the History of Emotions and Emotional Standards", American Historical Review 90 (1985), pp. 813-836.

Stone, Lawrence. The Family, Sex and Marriage in England 1500-1800. Short edition (London: Penguin Books, 1979).

Szijártó, István M. "Four Arguments for Microhistory", Rethinking History 6:2 (2002), pp. 209-215.

Terpastra, Nicholas. Lost Girls: Sex and Death in Renaissance Florence (Baltimore: Johns Hopkins University Press, 2012).

Thompson, E.P. The Making of the English Working Class (London: Victor Gollancz, 1963).

Thompson, E.P. "The Moral Economy of the English Crowd in the Eighteenth Century", in Customs in Common. Studies in Traditional Popular Culture (New York: The New Press, 1991), pp. 184-258.

Thompson, E.P. "The Moral Economy Reviewed", in Customs in Common. Studies in Traditional Popular Culture (New York: The New Press, 1991), pp. 259-351.

Thompson, E.P. "Time, Work-Discipline and Industrial Capitalism”, in Customs in Common: Studies in Traditional Popular Culture (New York: The New Press, 1991), pp. 352-403.

Tilly, Louise A., and Joan W. Scott. Women, Work and Family (New York: Holt, Rinehart and Winston, 1978). 
Tipps, Dean C. "Modernization Theory and the Comparative Study of Societies: A Critical Perspective", Comparative Studies in Society and History (Summer 1973), pp. 199-222.

Weber, Eugen. Peasants into Frenchmen: The Modernization of Rural France 1870-1914 (Stanford: Stanford University Press, 1976).

Weeks, Jeffrey. What Is Sexual History? (Cambridge: Polity Press, 2016).

Wilson, Norman J. History in Crisis? Recent Directions in Historiography (Upper Saddle River: Prentice Hall, 1999).

Wolff, Larry. Child Abuse in Freud's Vienna: Postcards from the End of the World (New York and London: New York University Press, 1988).

Wood, Nancy. "Memory's Remains: Les lieux de mémoire", History and Memory 6 (Spring/Summer 1994), pp. 123-149.

Wood, Nancy. Vectors of Memory: Legacies of Trauma in Postwar Europe (Oxford: Berg, 1999).

“Ævisaga Ljósvíkings”, Útvarpsblaðið 1:15 (1951), pp. 6-7. 